\title{
The effects of social media news that users trusted and verified on anxiety level and disease control perception in COVID-19 pandemic
}

\author{
Kullanıcıların güvendiği ve doğruladığı sosyal medya haberlerinin COVID-19 \\ Pandemisinde kaygı düzeyi ve hastalık kontrol algısı üzerindeki etkileri
}

\author{
Erman Şentürk1, Bahadır Geniş², Burak Erman Menkü³, Behcet Cosar ${ }^{4}$

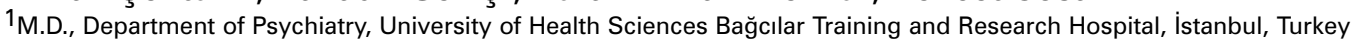 \\ https://orcid.org/0000-0001-9208-7905 \\ ${ }_{2}$ M.D., Department of Psychiatry, Çaycuma State Hospital, Zonguldak, Turkey https://orcid.org/0000-0001-8541-7670 \\ 3 M.D., 4 Prof., Department of Psychiatry, Gazi University Hospital, Ankara, Turkey https://orcid.org/0000-0002-8406-5439 \\ https://orcid.org/0000-0002-6422-499X
}

\section{SUMMARY}

Objective: Since the beginning of the pandemic, social media users have been bombarded with news about the number of cases and deaths, virus origin, vaccine development process, symptoms, transmission ways, prevention and treatment methods of COVID-19. This study was planned considering that the type of news sources and verification of the news was considerable and these affect the anxiety level and COVID-19 disease control perception. It was considered that reliance on different types of social media accounts (official or unofficial), verifying social media posts with other news sources, frequency of exposure to negative COVID-19 social media contents may have effects on this state. The aim of this study was to reveal the effects of these three variables on anxiety level and COVID-19 disease control perception of participants. Method: The sample consisted of 1516 adults. Participants filled out instruments for sociodemographic data, verification/trust on posts of official/unofficial social media accounts, state anxiety, COVID-19 disease control perception, frequency of exposure to positive/negative COVID-19 social media contents. Results: It was detected that as trust in COVID-19 posts of official social media accounts increased, anxiety level decreased and COVID-19 disease control perception increased. It was observed that as exposure to negative COVID-19 social media contents increased, anxiety level increased and COVID-19 disease control perception decreased. There was no significant correlation between anxiety level and verifying the accuracy of social media posts with other news sources. Discussion: While physical contact accelerates the spread of COVID-19 disease, it was thought that digital contact could be a tool that could decelerate individual and mass anxiety if used appropriately. It is obvious that posts that are reliable and verified will play a key role in controlling anxiety level and disease perception.

Key Words: COVID-19, coronavirus, social media, news, anxiety, health communication

(Turkish J Clinical Psychiatry 2021;24:23-32)

DOI:10.5505/kpd.2020.69772

\section{ÖZET}

Amaç: Sosyal medya kullanıcıları pandeminin başlangıcından itibaren COVID-19'a ilişkin vaka ve ölüm sayıları, virüs kaynağı, aşı geliştirme süreci, hastalık semptomları, bulaş yolları, önleme ve tedavi yöntemleri hakkında haberlerle bombardımana tutulmuştur. Bu çalışma, haber kaynaklarının türü ve haberlerin doğrulanmasının önemli olduğu ve bunların kaygı düzeyi ile COVID-19 hastalığı kontrol algısını etkilediği düşünülerek planlanmıştır. Farklı sosyal medya hesaplarına (resmi veya resmi olmayan) güvenmenin, sosyal medya paylaşımlarını diğer haber kaynakları ile doğrulamanın, olumsuz COVID-19 sosyal medya içeriklerine maruz kalma sıklığının bu durumu etkileyebileceği düşünülmektedir. Çalışmanın amacı, bu üç değişkenin katılımcıların anksiyete düzeyi ve COVID-19 hastalığı kontrol algısı üzerindeki etkilerini ortaya çıkarmaktır. Yöntem: Örneklem 1516 yetişkinden oluşmaktadır. Katılımcılar, sosyodemografik veri formu, sosyal medya teyit/güven ölçeği, durumluk kaygı ölçeği, COVID-19 hastalık kontrol algısı ölçeği ve pozitif / negatif COVID-19 sosyal medya içeriklerine maruz kalma sıklığının değerlendirildiği formlar doldurmuşlardır. Bulgular: Resmi sosyal medya hesaplarının COVID-19 paylaşımlarına olan güven arttıkça, kaygı düzeyinin azaldığı ve COVID-19 hastalığı kontrol algısının arttığı; negatif COVID-19 sosyal medya içeriklerine maruz kalma arttıkça anksiyete düzeyinin arttığı ve COVID-19 hastalığı kontrol algısının azaldığı görüldü. COVID-19'a ilişkin sosyal medya gönderilerini diğer haber kaynaklarından doğrulamak ile anksiyete düzeyi arasında önemli bir ilişki bulunamadı. Sonuç: Fiziksel temas COVID-19 hastalığının yayılmasını hızlandırırken, dijital temasın uygun şekilde kullanıldığı takdirde bireysel ve toplumsal kaygıyı azaltabilecek bir araç olabileceği düşünülmüştür. Güvenilir ve doğrulanmış gönderilerin kaygı düzeyini ve hastalık algısını kontrol etmede anahtar rol oynayabileceği dikkate alınmalıdır.

Anahtar Sözcükler: COVID-19, coronavirus, sosyal medya, haberler, anksiyete, sağlık iletişimi 


\section{INTRODUCTION}

Coronavirus disease (COVID-19) pandemic has created an unprecedented health crisis with over sixteen million cases by the end of July 2020. This pandemic has been changing world dynamics, causing significant economic, social and psychological issues $(1,2)$. From a mental health perspective, travel bans, social isolation, quarantine effects, prolonged curfew measures, slowing public services, restricted social activities, media information overload, daily updates on death and case numbers, health anxiety, fear of being unemployed caused global anxiety atmosphere (3-5). Feeling 'out of control' has triggered negative emotions. People faced with fear and anxiety about the health of themselves and loved ones, changes in eating habits, sleep problems, difficulty in concentrating, worsening in chronic health problems, increased alcohol and tobacco use (3).

Unlike other pandemics, the COVID-19 pandemic has been spreading around the world not only with the infectious agent but also through millions connected to each other by social media. Social media has a big potential to supply accurate information effectively if used appropriately in the health crisis (6). Research of previous epidemics revealed that social media had been effective in presenting recent news and relevant advice to the public $(7,8)$. Also, some researchers indicated that social media has a critical role as a way to understand public attitudes and acts, provide crisis communication and health messages (9-11).

Nowadays, social media users do not tend to evaluate the information they read while making important decisions about their health. $70 \%$ of websites offering information content had significant quality problems were reported (12). Increasing 'fake news' and 'misinformation' in the digital world make it difficult to access accurate information and anxiety is triggered (13). Such anxiety can be contagious, thanks to the possibilities of the digital world. Interpersonal anxiety transfer (transferring anxiety from one person to another) is defined as an object-directed social appraisal theory that is explained by the fact that, during infectious disease outbreaks, the person is in contact with another person's anxiety and begins to experience similar anxiety (14). Thus, anxiety spreads from individual to mass. Mass anxiety causes the community's demand for unnecessary treatment, diagnosis, or consultations, which could waste human and financial resources during a public health crisis like COVID-19 $(15,16)$.

Since the first COVID-19 case in Turkey, it was observed that many unfavorable contents were shared from social media accounts. We planned this study considering that posts with an unreliable source and whose truth was not verified increased anxiety level and disrupt the perception of disease control.

In this study, we aimed to reveal the effects of three variables on anxiety level and COVID-19 disease control perception of individuals. The first one of these variables was trust in different types of the COVID-19 news sources (official or unofficial social media accounts), the second was whether verifying the accuracy of social media posts about COVID-19 with other news sources or not, and the third was the frequency of exposure to negative COVID-19 social media contents. Our first hypothesis was that as trust in COVID-19 posts of official social media accounts (printed newspaper accounts, internet newspapers accounts, influential journalist accounts) increases, anxiety level decreases, and COVID-19 disease control perception increases. Our second hypothesis was that as trust in COVID-19 posts of unofficial social media accounts (social media phenomena accounts, friend and familiar accounts) and information sharing websites (user-generated content) increases, anxiety level increases, and COVID-19 disease control perception decreases. Our third hypothesis was that as verifying the accuracy of social media posts about COVID-19 with other news sources increases, anxiety level decreases, and COVID-19 disease control perception increases. Our fourth hypothesis was that as the exposure to negative COVID-19 social media contents (rumors and misinformation about the number of deaths caused by the virus, origin of the virus, vaccination, and treatment methods) increases, anxiety level increases, and COVID-19 disease control perception decreases. In connection with these four hypotheses, we anticipated that COVID-19 disease control 
perception would decrease as anxiety level increased.

\section{METHOD}

\section{Study Population and Setting}

We used an online survey to minimize face to face interactions and to facilitate participation during this emergency period. All data and informative forms in this cross-sectional study (names of researchers and their institutions, scope and purpose of the study, participation conditions, data privacy commitment form, survey instruments) were transferred to the survey link. Along with the survey link, the informative footnote about the title and purpose of the study were shared through social media applications (Twitter, Whatapp). 1516 adult volunteer participated in the study. All responses were anonymous and no personally identifiable information was requested. Participants who clicked on the link were asked to click on the confirmation button if they volunteered after reading the details of the study and privacy policies. Data was collected between June 10, 2020 and July 9,2020 . Only one exclusion criterion of the survey was being under the age of 18 .

\section{Data Collection}

Sociodemographic data were collected on age, gender, education status, chronic physical disease case, psychiatric treatment history.

We integrated social media posts about COVID-19 into the analysis model within two different categories as frequency of exposure to positive/negative COVID-19 social media contents. We determined the positive COVID-19 social media contents as informative contents about symptoms, transmission ways and prevention methods. We determined the negative COVID-19 social media contents as rumors and misinformation about the number of cases, deaths caused by the virus, origin of the virus, vaccination, and treatment methods. Participants were requested to mark three items on a five-point Likert scale related to the frequency of exposure to both positive/negative COVID-19 social media contents. $(1=$ never, $5=$ always $)$

Social Media Verification/Trust Scale (17) is a Turkish self-report scale and it consists of a total of 10 items including 4 items for accuracy of social media posts verification with other news sources, 3 items for trust in posts of an official social media accounts (printed newspaper accounts, internet newspapers accounts, influential journalist accounts), 3 items for trust in posts of unofficial social media accounts (phenomena accounts, friend and familiar accounts) and information sharing websites (user-generated content). In the scale that does not contain any reverse items, the relevant items of the sub-dimensions are averaged within themselves. The lowest score is 1 and the highest score is 5 for each item on the scale $(1=$ never, $5=$ always $)$. Higher scores in the verification sub-dimension mean that people verify the accuracy of social media posts with other news sources more. Higher scores of trust in official social media accounts sub-dimension means that people trust in posts of official social media accounts more. Higher scores of trust in unofficial social media accounts sub-dimension means that people trust in posts of unofficial social media accounts more. Cronbach's a value of the scale is .705. In our study, this value was found .704 .

State Anxiety Scale (STAI-S) (18) is a psychological inventory based on a 4-point Likert scale and consists of 20 questions on a self-report basis. The STAI-S measures anxiety and perceived threat about an event. Higher scores are positively correlated with higher levels of anxiety. State anxiety is defined as fear, worry, nervousness, discomfort, and the arousal of the autonomic nervous system induced by different situations that are perceived as dangerous. State anxiety refers to how a person feels against a perceived threat at that time, and this type of anxiety is usually temporary (19). The Turkish validity and reliability study was performed and the internal consistency and reliability of the Turkish form were found between 0.94 and 0.96 in Kuder Richardson alpha reliability. In our study, this value was found 0.89 .

There are many similarities between Swine flu (H1N1) and Coronavirus (COVID-19) disease. 
Both are mainly diseases of viral origin that affect the respiratory system and transmit through the respiratory droplets. Similar precautions such as frequent hand washing, wearing masks, and paying attention to social distance are taken to prevent both H1N1 and COVID-19 disease (20). So, the H1N1 control perception scale developed by Çırakoğlu in 2011 was adapted to COVID-19 by Geniş and et al. and its validity/reliability analysis was performed (21,22). COVID-19 Disease Control Perception Scale is self-report scale and it consists of 3 sub-dimensions. Participants were requested to mark each item on a five-point Likert scale $(1=$ not agree at all, $5=$ certainly agree $)$. The first sub-dimension (macro-control) is the belief in the effectiveness of government precautions to prevent COVID-19 disease. The second sub-dimension (micro-control) is the belief in the effectiveness of personal precautions to prevent COVID-19 disease. The third sub-dimension is the belief in the controllability of COVID-19 disease. The items evaluating the controllability sub-dimension are reverse scored. Higher scores in the macro control sub-dimension reflect an increased belief that the effectiveness of government precautions to prevent COVID-19 disease. Higher scores in the micro control sub-dimension reflect an increased belief that the effectiveness of personal precautions to prevent COVID-19 disease. Higher scores in the controllability sub-dimension reflect an increased belief that the disease will be controlled. The Cronbach's alpha value of the scale is 0.79 , and it was 0.74 in this study.

\section{Data analysis}

SPSS 23.0 and AMOS 22.0 program were used for the analysis of the study data. Descriptive statistics were specified with frequency, percentage, mean and standard deviation values. It is assumed that the normality assumption is provided when the skewness/kurtosis values of the data of numerical variables are between \pm 2 (23). Pearson correlation test was used to evaluate the relationship between numerical variables. In this study, the skewness/kurtosis values of Social Media Verification/Trust Scale sub-dimensions, COVID19 Disease Control Perception Scale sub-dimensions and age were found between (-1.247) (0.952). Therefore, it was accepted that the data show a normal distribution. Cronbach's alpha coefficient was used to determine the reliability of the scale. Statistical analysis was based on the significance level of $p<0.05$.

\section{Ethics}

Ethical approval for the study was granted by the ethical committee of Gazi University, Ankara with the number 2020-299.

\section{RESULTS}

Characteristics of the participants are presented in Table 1. There were more females than males in the

Table 1. Characteristics of the participants

\begin{tabular}{|c|c|c|c|}
\hline Variables & & $\mathrm{n}$ & $\%$ \\
\hline \multirow{2}{*}{ Gender } & Female & 990 & 65,3 \\
\hline & Male & 526 & 34,7 \\
\hline \multirow{2}{*}{ Marital status } & Married & 647 & 42,7 \\
\hline & Single & 869 & 57,3 \\
\hline \multirow{4}{*}{ Education status } & Primary school & 12 & 0,8 \\
\hline & Secondary school & 13 & 0,9 \\
\hline & High school & 151 & 10,0 \\
\hline & University & 1340 & 88,4 \\
\hline \multirow{2}{*}{ Parental status } & Yes & 539 & 35,6 \\
\hline & No & 977 & 64,4 \\
\hline \multirow{7}{*}{ Profession } & Healthcare worker & 299 & 19,7 \\
\hline & Officer & 192 & 12,7 \\
\hline & Private sector & 169 & 11,1 \\
\hline & Student & 280 & 18,5 \\
\hline & Unemployed & 163 & 10,8 \\
\hline & Retired & 68 & 4,5 \\
\hline & Others & 345 & 22,8 \\
\hline \multirow{2}{*}{ Chronic physical disease } & Yes & 265 & 17,5 \\
\hline & No & 1251 & 82,5 \\
\hline \multirow{2}{*}{$\begin{array}{l}\text { Psychiatric treatment } \\
\text { history }\end{array}$} & Yes & 505 & 33,3 \\
\hline & No & 1011 & 66,7 \\
\hline
\end{tabular}




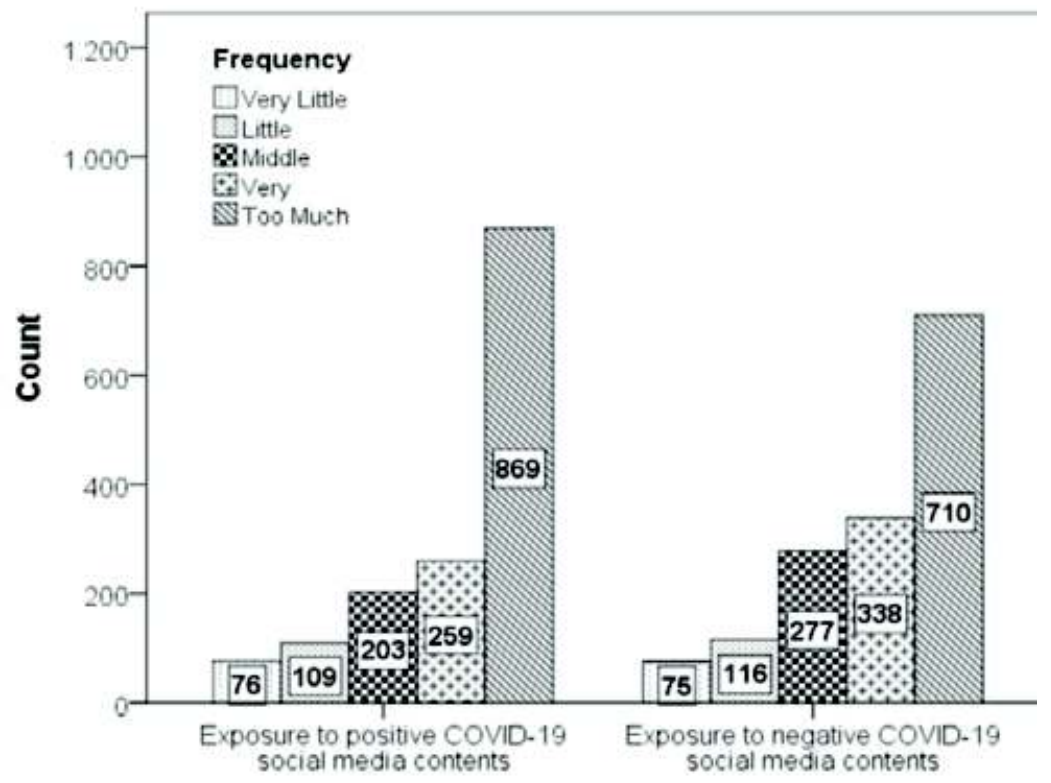

Figure 1. Frequency of exposure to positive/negative COVID-19 social media contents sample $(65.3 \%$ vs 34.7$) .57 .3 \%(n=869)$ of the overall sample were single. Educational status was compared in terms of gender and no significant difference was found $(\mathrm{X} 2=5.346, \mathrm{p}=0.148)$. The frequency of exposure to positive/negative COVID-19 social media contents are presented in Figure 1.

It was found that $869(57.3 \%)$ of the participants were exposed to too much positive and $710(46.8 \%)$ were exposed to too much negative social media contents. The assessment of COVID-19 Disease Control Perception Scale sub-dimensions by multiple linear regression analysis was in Table 2. In all sub-dimensions of the COVID-19 Disease Control Perception Scale, exposure to negative contents on the social media, and state anxiety levels were significant predictors.

Male gender $(\beta=0.100, p<0.001)$, being a parent ( $\beta=-0.131, p=0.001)$, high school or below education status $(\beta=-0.060, p=0.012)$, having no psychiatric treatment history $(\beta=0.052, p=0.032)$, less expositon to negative COVID-19 content on social media $(\beta=-0.078, p<0.001)$, trusting in posts of official social media accounts $(\beta=0.196, p$ $<0.001)$ and low anxiety level $(\beta=-0.230, p<$ 0.001 ) reflected that effecitiveness of macro control precautions were sufficent.

Older ages $(\beta=0.087, p=0.014)$, male gender $(\beta$ $=0.055, \mathrm{p}=0.032)$, high school and below educa- tion status $(\beta=-0.073, \mathrm{p}=0.003)$, having no chronic physical disease ( $\beta=0.068, p=0.008$ ), less exposition to negative content on social media $(\beta=$ $-0.054, p=0.031)$, verifying COVID-19 news with other news sources more frequently $(\beta=0.050, p$ $=0.041$ ), trust in COVID-19 posts of official social media accounts $(\beta=0.102, p<0.001)$ and unofficial social media accounts $(\beta=0.128, \mathrm{p}<0.001)$ and low anxiety level $(\beta=-0.150, p<0.001)$ reflected that effecitiveness of micro control precautions were sufficent.

Controllability sub-dimension was predicted by younger ages $(\beta=-0.077, p=0.033)$, less exposition to negative COVID-19 content on social media $(\beta=-0.133, p<0.001)$, verifying COVID-19 posts with other news sources $(\beta=0.060, \mathrm{p}=$ $0.017)$ and low anxiety level $(\beta=-0.162, p<0.001)$.

The assessment of the relationships between the sub-dimensions of the scales was in Table 3. There was a negative relationship between state anxiety level and trust in COVID-19 posts of official social media accounts $(\mathrm{r}=-0.055, \mathrm{p}=0.034)$, macro-control $(\mathrm{r}=-0.313, \mathrm{p}<0.001)$, micro-control $(\mathrm{r}=-0.207$, $\mathrm{p}<0.001)$, controllability $(\mathrm{r}=-0.193, \mathrm{p}<0.001)$. On the contrary, there was a positive relationship between state anxiety level and exposure to negative content on social media $(\mathrm{r}=0.213, \mathrm{p}<0.001)$. There was a positive correlation between the verification sub-dimension of the Social Media Verification/Trust Scale and micro-control 
Senturk E, Genis B, Menku EB, Cosar B.

\begin{tabular}{|c|c|c|c|c|c|c|c|c|c|}
\hline \multirow{2}{*}{ Variables } & \multicolumn{3}{|c|}{ Macro-control } & \multicolumn{3}{|c|}{ Micro-control } & \multicolumn{3}{|c|}{ Controllability } \\
\hline & & $\mathrm{t}$ & $\mathrm{p}$ & & $\mathrm{t}$ & $\mathrm{p}$ & & $\mathrm{t}$ & $\mathrm{p}$ \\
\hline Age & 0,067 & 2,747 & 0,006 & 0,078 & 3,076 & 0,002 & $-0,073$ & $-2,814$ & 0,005 \\
\hline $\begin{array}{l}\text { Gender }(\text { Female }=1, \\
\text { Male }=2)\end{array}$ & 0,114 & 4,633 & $<0,001$ & 0,064 & 2,526 & 0,012 & 0,050 & 1,928 & 0,054 \\
\hline $\begin{array}{l}\text { Educational status (High } \\
\text { school and below=1, } \\
\text { University and above=2) }\end{array}$ & $-0,066$ & $-2,778$ & 0,006 & $-0,072$ & $-2,927$ & 0,003 & $-0,034$ & $-1,337$ & 0,182 \\
\hline $\begin{array}{l}\text { Exposure to positive } \\
\text { COVID-19 social media } \\
\text { content } \\
(\text { never }=1 \text {,always }=5 \text { ) }\end{array}$ & 0,027 & 1,145 & 0,252 & $-0,036$ & $-1,466$ & 0,143 & $-0,009$ &,- 365 & 0,715 \\
\hline $\begin{array}{l}\text { Exposure to negative } \\
\text { COVID-19 social media } \\
\text { content } \\
(\text { never }=1 \text {,always=5) }\end{array}$ & $-0,087$ & $-3,550$ & $<0,001$ & $-0,058$ & $-2,298$ & 0,022 & $-0,134$ & $-5,181$ & $<0,001$ \\
\hline $\begin{array}{l}\text { Social media } \\
\text { verification/trust scale } \\
\text { (Verification sub- } \\
\text { dimension) }\end{array}$ & $-0,004$ & $-0,189$ & 0,850 & 0,051 & 2,077 & 0,038 & 0,060 & 2,388 & 0,017 \\
\hline $\begin{array}{l}\text { Social media } \\
\text { verification/trust scale } \\
\text { (Trust in posts of official } \\
\text { social media accounts) }\end{array}$ & 0,206 & 7,956 & $<0,001$ & 0,102 & 3,797 & $<0,001$ & 0,020 &, 715 & 0,475 \\
\hline $\begin{array}{l}\text { Social media } \\
\text { verification/trust scale } \\
\text { (Trust in posts of } \\
\text { unofficial social media } \\
\text { accounts) }\end{array}$ & $-0,031$ & $-1,200$ & 0,230 & 0,134 & 5,000 & $<0,001$ & 0,017 & ,619 & 0,536 \\
\hline State anxiety scale & $-0,238$ & $-9,517$ & $<0,001$ & $-0,158$ & $\begin{array}{l}-6,099 \\
\end{array}$ & $<0,001$ & $-0,162$ & $-6,094$ & $<0,001$ \\
\hline $\mathrm{F}$ & 33,386 & & & 19,930 & & & 11,721 & & \\
\hline $\mathrm{p}$ & $<0,001$ & & & $<0,001$ & & & $<0,001$ & & \\
\hline $\mathrm{R}^{2}$ & 0,166 & & & 0,106 & & & 0,065 & & \\
\hline Adjusted $\mathrm{R}^{2}$ & 0,161 & & & 0,101 & & & 0,060 & & \\
\hline
\end{tabular}

$(\mathrm{r}=0.053, \mathrm{p}=0.036)$, and controllability $(\mathrm{r}=0.055$, $\mathrm{p}=0.032)$.

\section{DISCUSSION}

Social media has been the biggest source of the highly contagious panic atmosphere that spreads faster than the virus in the COVID-19 pandemic process (24). In the current study, it was considered that reliance on different types of social media accounts (official or unofficial), verifying social media posts with other news sources, frequency of exposure to negative COVID-19 social media contents may cause effects on anxiety level and COVID-19 disease control perception.

First of all its seen that as trust in COVID-19 posts of official social media accounts increased, anxiety level decreased and both macro-control and microcontrol perception dimensions of disease increased (Table 3). Some researches stated that official news sources of government agencies, news media and journalists are more reliable and effective than unofficial sources such as peers in natural disasters
$(25,26)$. Sharing accurate information by official accounts helps people to change their perception of crisis violence positively. Accurate information provided by the authorities increases public awareness and perceived risk of the crisis severity among social media users. This state helps individuals to decrease their anxiety levels by changing their attitudes and moods positively $(27,28)$. In the regression analysis, one of the most important factors in increasing the macro-control and micro-control perception was increased trust in COVID-19 posts of official social media accounts (Table 2). Hence we understand the importance of accessing accurate information, assimilating this information, and turning our negative feelings into positive thanks to this information, in control of the pandemic both personally and socially.

Surprisingly we found that as trust in COVID-19 posts of unofficial social media accounts increased, only the micro-control perception subdimension of COVID-19 disease increased (Table 3). This result has shown us that unofficial social media accounts can also increase belief in the effectiveness of the personal precautions for COVID-19. Thus, we can 
predict that posts from accounts of familiar or friends may be important in terms of personal precautions regardless of individual anxiety level. Usually, social media users can accept polemics as true if it originates from trustworthy sources or endorses their political and social world-views (29). Some studies indicated that scientific misinformations by unofficial social media accounts have a political aspect. This can be used as a political weapon by reducing confidence in governments and health policies $(30,31)$. But no correlation was found between trust in these accounts and macrocontrol in the current study.

Although frequent exposure to both positive and negative social media posts increases the need of verifying these with other news sources, we found that whether verifying the accuracy of social media posts about COVID-19 with other news sources didn't have significant positive correlations with anxiety level and macro-control perception of
COVID-19 disease (Table 3). This unexpected result may be related to the fact that the first impression in digital media is very important and difficult to change (32). But there was a significant positive correlation between the verifying the accuracy of social media posts about COVID-19 with other news sources and both controllability and micro-control perception of COVID-19 disease. Thus, we can emphasize that accessing accurate information increases the belief in the controllability of COVID-19 and the effectiveness of personal precautions.

As exposure to negative COVID-19 social media contents increased, we found that anxiety level increased and each sub-dimension of the disease control perception decreased (Table 3). Rumors, misinformation, and fake news arose on various social media platforms about the etiology, outcomes, prevention, and treatment of the COVID19 disease in this process (33). Reason why the fake

Table 3. Assessment of the relationships between the sub-dimensions of the scales

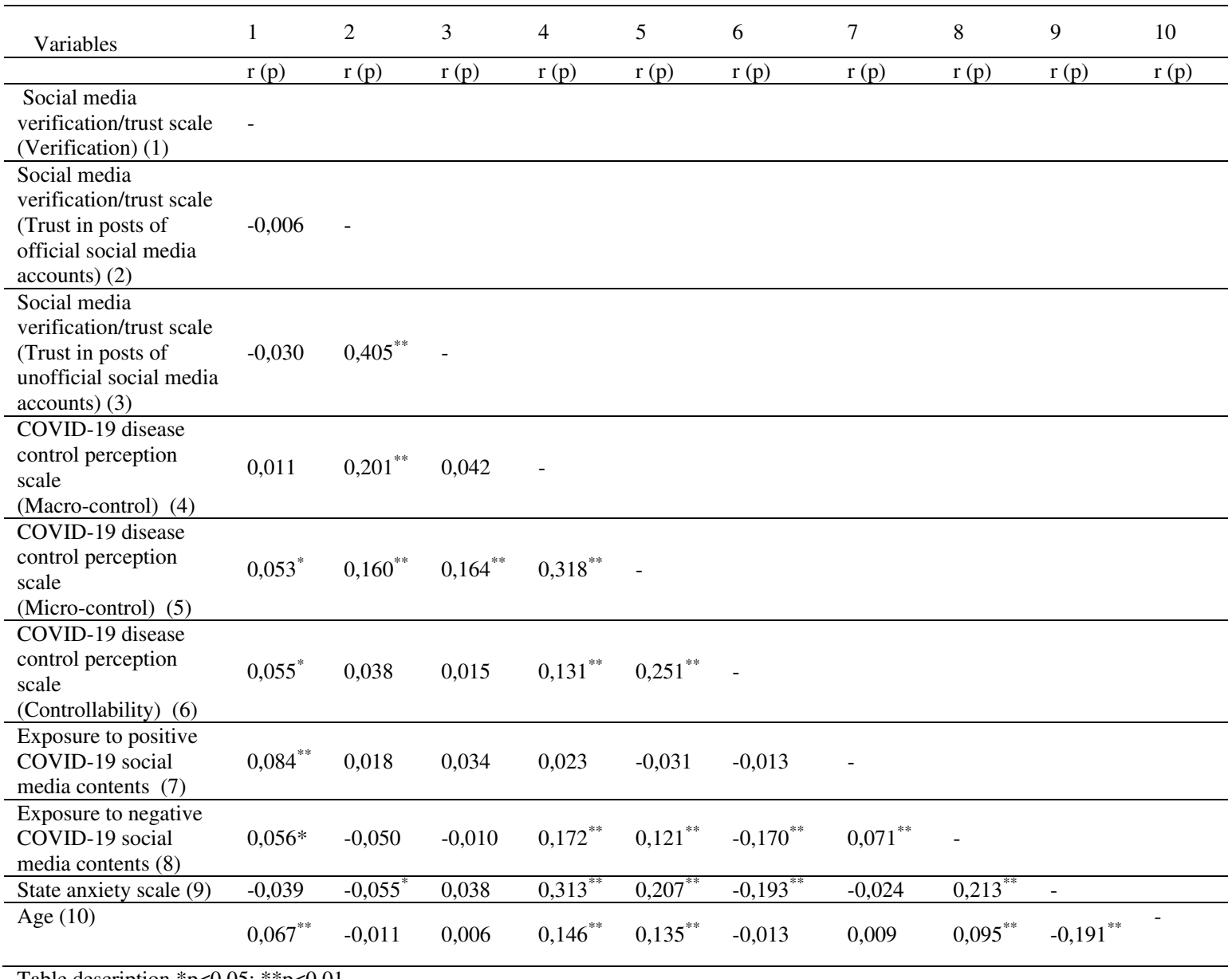

Table description $* \mathrm{p}<0,05 ; * * \mathrm{p}<0,01$ 
news and rumors are shared more on social media may be related to the attractiveness and shocking effect of the content rather than their accuracy. Misinformation endangers public health by causing mass anxiety (as a result of overestimating the crisis severity) and more dangerously, public indifference to take recommended protective measures (as a result of underestimating the health threat) (28). Fake news and rumors about COVID-19 disturbs protective behavior (handwashing, social distance, etc.) and care-seeking strategies (unnecessary hospital admissions and unscientific treatments, etc.) (33). Whereas positive news, backed by active public health interventions, increases public awareness and confidence in virus control, reducing mass anxiety and panic (34). Similar to our findings, it was indicated that repeated exposure to distressing media content and excessive information is likely causing increased levels of stress, anxiety (35). In our study, while frequent exposure to negative news contents about COVID-19 was one of the factors that led to a decrease in each sub-dimension of perception of disease control. Interestingly, exposure to positive news contents about COVID-19 had no positive effect on control perception (Table 2). This result helps us to consider that negative COVID-19 social media contents are more impressive than positive COVID-19 social media contents.

It was found that as anxiety level increased, each sub-dimension of disease control perception decreased (Table 3). Negative emotions such as anxiety and worry have a direct or mediated effect on behaviors related to potential health risks in health and risk communication (36). High levels of fear about COVID-19 disease and its consequences may prevent individuals from thinking clearly and rationally (37). It is known that the relationship between fear and protective behavior is not linear. Neither less nor more only moderate fear motivates people to increase protective behavior (38). In the regression analysis, the most important factor that decreases each sub-dimension of the COVID-19 disease control perception is high anxiety level as we expected (Table 2). In this process, anxiety spread like a virus, affecting people and communities. It has proven to be a crucial element to tackle in such public health crises.
Factors that decrease the macro-control and microcontrol perception of the disease include females and higher education status. This result may be related to the fact that both variables have individuals with higher anxiety levels who expose to COVID-19 social media posts more. We found that younger age decreased the micro-control perception of the disease, older age decreased the controllability perception of the disease (Table 2). Overdose of negative news such as 'considering COVID-19 as a disease of older people' may cause elderly individuals to feel more anxious and believe in the uncontrollability of the disease.

To the best of our knowledge, this study is the first to investigate the relationship between the qualification (types, contents) of social media posts about COVID-19, frequency of exposure to these posts, anxiety level and COVID-19 disease control perception. Several limitations in our investigation require attention. First, this study has several limitations mainly related to the cross-sectional design, lack of a longitudinal follow-up period and the usage of self-assessment scales. Second, the sampling of our study is snowball sampling and does not reflect all of the research universe. Third, internet access was required for individuals to participate in the study and most of the participants were university graduates. Fourth, the STAI-S scale in the current study measures the general anxiety levels of people about events rather than the anxiety and fear specific to the pandemic. Fifth, unemployment, mobbing, burnout, family and other personal losses, fears, domestic violence specific to the pandemic period were not measured. Sixth, we suggested the negative COVID-19 social media contents as rumors and misinformation about the number of cases and deaths caused by the virus, origin of the virus, vaccination, and treatment methods. Therefore, we did not make a clear distinction between negative news contents and misinformation. But it was not possible to evaluate whether social media posts about COVID-19 was true or false in such a study. However, truths can be manipulated as false. Also, the negative perception of news or posts may be related to individual differences. Seventh, presence of psychiatric disorders was not included in the study due to the design of the study. 


\section{CONCLUSIONS}

Given the social distancing, quarantine, curfew, and isolation directives, social media usage allows the maintenance of social proximity without physical contact. While physical contact accelerates the spread of the disease, digital contact provides a tool that can decelerate pandemic if used appropriately. This is the first pandemic of the information era. In this global health crisis, humanity have encountered so many misinformations such as origin, transmission ways, symptoms, effects, treatment methods, and vaccination studies about a disease than ever before. This situation reached a level that would threaten physical and mental health.

Finally, actual steps have been taken regarding the issue. Social media companies (Facebook, Twitter) have started taking a series of precautions to prevent misinformation about COVID-19 since last month (39). Facebook declared that warning notifi- cations would be sent to users who liked or commented on misinformation posts about COVID-19. Twitter announced that the content, which is considered misinformation, will include warnings such as "This content of post contradicts the information provided by public health experts". Eliminating misinformation can help social media users learn and disseminate accurate information, helping to reduce danger for both themselves and others. Removing false claims and fake news about COVID-19 and the further declaration of corrective and accurate information shared by specialists is crucial to protect public health in such crises.

Correspondence address: M.D., Ali Karayagmurlu, Department of Child and Adolescent Psychiatry, Faculty of Medicine, Istanbul University, Istanbul, Turkey dralikarayagmurlu@gmail.com

\section{REFERENCES}

1. Chen Y, Li L. SARS-CoV-2: virus dynamics and host response. Lancet Infect Dis. 2020;20:515-516. doi:10.1016/S1473-3099(20)30235-8

2. Zhu N, Zhang D, Wang W, Li X, Yang B, Song J, Zhao X, Huang B, Shi W, Lu R. A novel coronavirus from patients with pneumonia in China. N Engl J Med. 2020;382:727-733. doi:10.1056/NEJMoa2001017

3. Buheji M, Jahrami H, Dhahi A. Minimising Stress Exposure During Pandemics Similar to COVID-19. Int J Psychol Behav Sci. 2020;10:9-16

4. Eisazadeh F, Aliakbari Dehkordi M, Aghajanbigloo S. Psychological consequences of patients with coronavirus (COVID-19): A Qualitative Study. Biquarterly Iranian Journal of Health Psychology. 2020;2:9-20.

5. Ho C, Chee C, Ho R. Mental health strategies to combat the psychological impact of COVID-19 beyond paranoia and panic. Ann Acad Med Singapore. 2020;49:155-160.

6. Chan AKM, Nickson CP, Rudolph JW, Joynt GM, Lee A. Social media for rapid knowledge dissemination: early experience from the COVID-19 pandemic. Anaesthesia. 2020. doi:10.1111/anae.15057

7. Househ M. Communicating Ebola through social media and electronic news media outlets: A cross-sectional study. Health Informatics J. 2016;22:470-478.

8. Omrani AS, Shalsoub S. Middle East respiratory syndrome coronavirus (MERS-CoV): what lessons can we learn? J Hosp Infect. 2015;91:188-96.

9. Jordan SE, Hoved SE, Fung IC, Liang H, Fu K, Tse Z. Using Twitter for public health surveillance from monitoring and pre- diction to public response. Data. 2019;4:6.

10. Shah Z, Surian D, Dyda A, Coiera E, Mandl KD, Dunn AG. Automatically Appraising the Credibility of Vaccine-Related Web Pages Shared on Social Media: A Twitter Surveillance Study. J Med Internet Res. 2019;21:e14007. doi:10.2196/14007

11. Sinnenberg L, Buttenheim AM, Padrez K, Mancheno C, Ungar L, Merchant RM. Twitter as a tool for health research: a systematic review. Am J Public Health. 2017;107:e1-e8.

12. Eysenbach G, Powell J, Kuss O, Sa E. Empirical studies assessing the quality of health information for consumers on the world wide web: a systematic review. Jama. 2002;287:2691-2700. doi:10.1001/jama.287.20.2691

13. Vogel L. Viral misinformation threatens public health. Can Med Assoc J. 2017;189:E1567-E1567.

14. Parkinson B, Simons G. Worry spreads: Interpersonal transfer of problem-related anxiety. Cogn Emot. 2012;26:462-479. doi:10.1080/02699931.2011.651101

15. Cuan-Baltazar JY, Munoz-Perez MJ, Robledo-Vega C, Perez Zepeda MF, Soto-Vega E. Misinformation of COVID-19 on the Internet: Infodemiology study. JMIR Public Health Surveill. 2020;6:e18444. doi:10.2196/18444

16. Hogue MC, Doran E, Henry DA. A prompt to the web: the media and health information seeking behaviour. PLoS One. 2012;7:e34314-e34314. doi:10.1371/journal.pone.0034314

17. Çömlekçi MF, Başol O. Sosyal medya haberlerine güven ve kullanıcı teyit alışkanlıkları üzerine bir inceleme. Galatasaray Üniversitesi İletişim Dergisi. 2019;30:55-77.

18. Spielberger C, Gorsuch R, Lushene R. (1970). STAI Manual for the State-Trait Anxiety Inventory (Palo Alto, CA, Consulting 
Psychologists Press): Inc.

19. Spielberger CD, Sydeman SJ. The Use of Psychological Testing for Treatment Planning and Outcome Assessment, Maruish ME, ed. New Jersey: Lawrence Erlbaum Associates; 1994.

20. Roy D, Tripathy S, Kar SK, Sharma N, Verma SK, Kaushal V. Study of knowledge, attitude, anxiety \& perceived mental healthcare need in Indian population during COVID-19 pandemic. Asian J Psychiatr. 2020;51:102083. doi:https://doi.org/10.1016/j.ajp.2020.102083

21. Çirakoglu OC. Domuz Gribi (H1N1) Salginiyla Iliskili Algilarin, Kaygi ve Kaçinma Düzeyi Degiskenleri Baglaminda Incelenmesi/The Investigation of Swine Influenza (H1N1) Pandemic Related Perceptions in terms of Anxiety and Avoidance Variables. Türk Psikoloji Derg. 2011;26:49-69.

22. Geniş B, Gürhan N, Koç M, Geniş C, Sirin B, Çırakoğlu OC, Coşar B. COVID-19 pandemisine ilişkin algı ve tutum ölçeklerinin geliştirilmesi. Pearson Journal of Social Sciences and Humanities 2020; 7: 306-328.

23. D'Agostino RB, Belanger A, D'Agostino RB. A Suggestion for Using Powerful and Informative Tests of Normality. Am Stat 1990;44:316-21

24. Depoux A, Martin S, Karafillakis E, Preet R, Wilder-Smith A, Larson $\mathrm{H}$. The pandemic of social media panic travels faster than the COVID-19 outbreak. J Travel Med. 2020;27.

25. Schultz F, Utz S, Göritz A. Is the medium the message? Perceptions of and reactions to crisis communication via twitter, blogs and traditional media. Public Relat Rev. 2011;37:20-27.

26. Van Der Meer TGLA. Public frame building: The role of source usage in times of crisis. Communication Research. 2018;45:956-981.

27. Bish A, Michie S. Demographic and attitudinal determinants of protective behaviours during a pandemic: a review. Br J Health Psychol. 2010;15:797-824 doi:10.1348/135910710X485826

28. Van Der Meer TGLA, Jin Y. Seeking formula for misinformation treatment in public health crises: The effects of corrective information type and source. J Health Commun. 2020;35:560-575.

29. Nielsen RK, Fletcher R, Newman N, Brennen JS, Howard PN. Navigating the 'infodemic': How people in six countries access and rate news and information about coronavirus. UK: The Reuters Institute for the Study of Journalism y University of Oxford. 2020

30. Guess A, Nyhan B, Reifler J. Selective exposure to misinformation: Evidence from the consumption of fake news during the 2016 US presidential campaign. European Research Council. 2018;9:4.

31. Singer PW, Brooking ET. LikeWar: The weaponization of social media. Eamon Dolan Books; 2018.

32. Ramirez Jr A. The effect of anticipated future interaction and initial impression valence on relational communication in computer-mediated interaction. Commun Stud. 2007;58:53-70.

33. Tasnim S, Hossain M, Mazumder H. Impact of rumors or misinformation on coronavirus disease (COVID-19) in social media. J Prev Med Public Health. 2020;53:171-174.

34. Liu Q, Zheng Z, Zheng J, Chen Q, Liu G, Chen S, Chu B, Zhu H, Akinwunmi B, Huang J. Health Communication Through News Media During the Early Stage of the COVID-19 Outbreak in China: Digital Topic Modeling Approach. J Med Internet Res. 2020;22:e19118.

35. Gao J, Zheng P, Jia Y, Chen H, Mao Y, Chen S, Wang Y, Fu $\mathrm{H}$, Dai J. Mental health problems and social media exposure during COVID-19 outbreak. PLoS One. 2020;15:e231924. doi:10.1371/journal.pone.0231924

36. Allen Catallier JR, Yang ZJ. Trust and affect: how do they impact risk information seeking in a health context?. J Risk Res. 2012;15:897-911.

37. Ahorsu DK, Lin CY, Imani V, Saffari M, Griffits MD, Pakpour AH. The Fear of COVID-19 Scale: Development and Initial Validation. Int J Ment Health Addict. 2020;1-9.

38. Janis IL. Advances in experimental social psychology. Elsevier; 1967.

39. Limaye RJ, Sauer M, Ali J, Bernstein J, Wahl B, Barnhill A, et al. Building trust while influencing online COVID-19 content in the social media world. Lancet Digit Health. 2020;2:677-8. 